\title{
SISTEM PRODUKSI KELAPA SAWIT DAN KARET DENGAN MEMBANDINGKAN HASIL PRODUKSI MENGGUNAKAN SIMULASI (STUDI KASUS: KABUPATEN KUANTAN SINGINGI)
}

\author{
${ }^{1)}$ Ira Puspita Sari, ${ }^{2}$ Robi Wahyu \\ 1)2) Jurusan Teknik Informatika, Fakultas Teknik, Universitas Abdurrab, Pekanbaru \\ Jln. Riau Ujung No. 73, Kota Pekanbaru, 28292, Indonesia \\ E-Mail: ira.puspita.sari@univrab.ac.id,robiwahyu449@gmail.com
}

\begin{abstract}
ABSTRAK
Peningkatan produksi hasil pertanian sangat di perlukan untuk mempertahankan dan meningkatkan perekonomian rumah tangga petani. Seiring dengan meningkatnya keanekaragaman jenis pertanian, terutama pertanian tanaman keras kelapa sawit dan karet. Keaneka ragaman cara petani untuk meningkatkan penghasilan pertanian dengan menanam kelapa sawit dan karet, membuat petani tidak fokus dalam satu jenis tanaman yang akan di tanam, bahkan ada yang beralih dari tanan karet ke tanaman kelapa sawit atau sebaliknya. Dengan adanya peningkatan dan pemanfaatan hasil produksi banyak para petani merasa ragu untuk menanam lahan mereka dengan kelapa sawit atau dengan karet. Untuk mengatasi keraguan di masyarakat perlu adanya model dengan simulasi hasil yang di peroleh dengan luas, waktu tanam, modal yang sama dan menghasilkan hasil yang berbeda. Hasil yang di harapkan adalah menentukan perbandingan produksi antara kelapa sawit dan karet.
\end{abstract}

Kata kunci: sawit, karet, petani, produksi

\section{ABSTRACT}

Increased production of agricultural products is needed to maintain and improve the farm household's economy. Along with the increasing diversity of types of agriculture, especially agricultural oil palm and rubber crops. The diversity of farmers' ways to increase agricultural income by planting oil palm and rubber leaves farmers unfocused on one type of crop to be planted, some even switching from rubber to palm oil crops or vice versa. With the increase and utilization of the produce many farmers are hesitant to plant their land with oil palm or with rubber. To overcome the doubts in the community there needs to be a model with simulated results obtained with area, planting time, the same capital and produce different results. The expected result is to determine the ratio of production between oil palm and rubber

Keywords: palm, rubber, farmer, production

\section{PENDAHULUAN}

Peningkatan produksi hasil pertanian sangat di perlukan untuk mempertahankan dan meningkatkan perekonomian rumah tangga petani. Seiring dengan meningkatnya keanekaragaman jenis pertanian, terutama pertanian tanaman keras,yaitu kelapa sawit dan karet. Strategi petani swadaya kelapa sawit dan karet dalam mengelola perkebunan dari penggunaan bibit, menanam, merawat, sampai pemasaran semua dilakukan sesuai kemampuan masing-masing petani dari segi pembiayaan seperti pembelian pupuk, pembelian pestisida, jasa pemetik buah, biaya pengangkutan, selain itu variasi luas lahan yang dimiliki, umur perkebunan dalam hal ini umur tanaman kelapa sawit setelah ditanam , dan pemasaran hasil panen yang dijual ke pengepul, KUD (Koperasi Unit Desa), dan ke perusahaan langsung yang masing-masing harga jualnya berbeda beda (Akhbianor, 2015).

Perkembangan penanaman kelapa sawit di wilayah Kuantan Singingi sangat pesat sehinggan para petani yang semulanya mengandalkan sawah dan ladang, sekarang banyak beralih ke tanaman kelapa sawit dan 
karet. Perkembangan tersebut di tunjukkan dengan adanya peningkatan hasil olahan bahan mentah dari kelapa sawit dan karet di pabrik-pabrik kelapa sawit hingga mencapai $20 \%$ setiap tahunnya, penambahan pewrsentase ini terus menerus setiap tahunnya (Gustina, 2015).

Berdasarkan data Badan Pusat Statistik Provinsi Riau hingga pada tahun 2015 luas perkebunan karet di kabupaten Kuantan Singingi mencapai 146.474 Ha dan kelapa sawit mencapai $128.538 \mathrm{Ha}$ (BPS Provinsi Riau, 2015). Peningkatan data tersebut berarti para petani semakin giat pemanfaatan lahan sebagai tanaman kelapa sawit dan karet, sehingga petani memiliki beberapa trategi agar mengurangi modal dan ketergantungan dengan pihak lain. Perbedaan hasil penjualan antara kelapa sawit dan karet beserta perawan membaut para petani mulai meninggalkan karet, hal ini dikarenakan aspek ekonomis berpengaruh terhadap alih fungi lahan, karena dari tingkat harga produksi sawit lebih besar dibanding produksi karet dan tingkat keuntungan sawit lebih besar, sehingga dengan beralih fungsi lahan karet menjadi lahan sawit pendapatan responden meningkat (Sari, 2014).

Pendapatan petani swadaya kelapa sawit dari penjualan hasil panen perkebunan kelapa sawit sangat bervariasi dari nominal paling kecil yaitu Rp.1.000.000,00 sampai paling besar yaitu Rp.8.000.000,00, setelah diambil nilai rata-rata dari keseluruhan responden pendapatan petani tiap bulannya memiliki pendapatan sebesar Rp2.985.000,00 perbulan (Akhbianor, 2015). Keaneka ragaaman cara petani untuk meningkatkan penghasilan pertanian dengan menanam kelapa sawit dan karet, membuat petani tidak pokus dalam satu jenis tanaman yang akan di tanam, bahkan ada yang beralih dari tanan karet ke tanaman kelapa sawit atau sebaliknya. Peralihan ini di sebabkan peningkatan penghasilan dengan perawatan mulai penanaman hingga menghasilkan tidak ada perbandingan penghasilan yang jelas. Untuk itu memudahkan petani dalam menentukan pilhan harus dengan cara mengevaluasi hasil produksi perbandingan antara kelapa sawit dan karet dengan simulasi (Sari, 2010).

Dengan adanya peningkatan dan pemanfaatan hasil produksi banyak para petani merasa ragu untuk menanam lahan mereka dengan kelapa sawit atau dengan karet, hal keraguan di masyarakat perlu adanya simulasi hasil yang di peroleh dengan luas, waktu tanam, modal yang sama dan menghasilkan hasil yang berberda. Untuk itu penulis tertarik meneliti dengan judul "Sistem Produksi Kelapa Sawit Dan Karet Dengan Membandingkan Hasil Produksi Menggunakan Simulasi Studi Kasus: Kabupaten Kabupaten Kuantan Singingi”.

Penelitian yang pernah di lakukan oleh Sari (2015) dengan judul "Analisis Faktor Yang Mempengaruhi Alih Fungsi Lahan Karet Menjadi Lahan Sawit Pada Anggota Kud Langgeng Kecamatan Logas Tanah Darat Kabupaten Kuantan Singingi”. Penelitian ini bertujuan mengetahui faktor-faktor yang mempengaruhi alih fungsi lahan karet menjadi lahan sawit. Populasi penelitian ini adalah seluruh petani sawit yang memiliki luas laan 2 hektar. Pengambilan sampel dilakukan dengan teknnik Purposive Sampling. Data dikumpulkan melalui wawancara dan observasi. kemudian dianalisis secara deskriptif. peneitin menemukan bahwa semua aspek mempengaruhi petani beralih fungsi lahan karet menjadi lahan sawit 
yaitu aspek ekonomi, aspek lingkungan dan asek teknis. Studi ini merekomendasikan agar pemerintah memperhatikan perluasan luas lahan sawit oleh pemerintah sesuai dengantata ruang daerah yang telah diatur pemerintah sehingga menghindari pemanasan global.

Bedasarkan penelitian yang di lakukan Akhbianor (2015), dengan judul “ Strategi Petani Swadaya Kelapa Sawit Dalam Mengelola Perkebunan Kelapa Sawit Di Desa Sungai Kupang Jaya Kecamatan Kelumpang Selatan Kabupaten Kotabaru". Penelitian ini bertujuan untuk mengetahui bagaimana strategi petani dalam mengelola perkebunannya dan mengetahui tingkat pendapatan petani. Populasi dari penelitian ini adalah seluruh petani swada kelapa sawit yang berjumlah 200 dan diambil sampel sejumlah 132 orang. Metode penelitian ini adalah metode deskriptif kuantitatif. Teknik pengumpulan data terdiri dari data primer dan data sekunder. Teknik pengumpulan data primer diproleh dari observasi dengan menggunakan angket, dan teknik pengumpulan data sekunder diperoleh dari Kantor Kecamatan Kelumpang Selatan, Kantor Kepala Desa Sungai Kupang Jaya, dan Mantri Tani (Penyuluh Pertanian). Teknik pengolahan data menggunakan editing, coding, scoring dan tabulating. Teknik analisis data menggunakan persentase. Hasil penelitian ini menunjukan bahwa, strategi petani swadaya kelapa sawit Desa Sungai Kupang Jaya Kecamatan Kelumpang Selatan Kabupaten kotabaru dalam mengelola perkebunan dari penggunaan bibit, menanam, merawat, sampai pemasaran semua dilakukan sesuai kemampuan masing-masing petani dari segi pembiayaan seperti pembelian pupuk, pembelian pestisida, jasa pemetik buah, biaya pengangkutan, selain itu variasi luas lahan yang dimiliki, umur perkebunan dalam hal ini umur tanaman kelapa sawit setelah ditanam, dan pemasaran hasil panen yang dijual ke pengepul, KUD (Koperasi Unit Desa), dan ke perusahaan langsung yang masingmasing harga jualnya berbeda-beda. Pendapatan petani swadaya kelapa sawit Desa Sungai Kupang Jaya Kecamatan Kelumpang Selatan dari penjualan hasil panen perkebunan kelapa sawit sangat bervariasi dari nominal paling kecil yaitu Rp.1000.000,00 sampai paling besar yaitu Rp.8.000.000,00, setelah diambil nilai rata-rata dari keseluruhan responden pendapatan petani tiap bulannya memiliki pendapatan sebesar Rp2.985.000,00 perbulan.

Berdasarakan penelitian yang di lakukan Agustina (2015), dengan judul "Pengaruh Luas Lahan Terhadap Pendapatan Petani Karet Di Desa Pulau Ingu Kpecamatan Benai Kabupaten Kuantan Singingi”, Penelitian ini bertujuan untuk mengatahui pengaruh luas lahan terhadap pendapatan petani karet di Desa Pulau Ingu Kecamatan Benai Kabupaten Kuantan Singingi. Penelitian ini dilakukan di Desa Pulau Ingu dari bulan Agustus 2014 sampai selesai. Metode penelitian yang digunakan adalah metode deskriptif kuantitatif. Populasi adalah semua petani karet di Desa Pulau Ingu sebanyak 60 responden yang di pilih sebagai sampel. Instrument penggumpulan data yang digunakan adalah angket dan data di analisis dengan model regresi linear sederhana. Hasil penelitian ini menunjukkan bahwa luas lahan berpengaruh signifikan terhadap pendapatan petani karet di Desa 
Pulau Ingu Kecamatan Benai Kabupaten Kuantan Singingi. Hal ini dilihat dari hasil uji regresi linear sederhan dengan taraf signifikan 5\% diperoleh nilai $\mathrm{f}$ untuk luas lahan $<1$ Ha F-hitung $>$ Ftabel (Fhitung $1894.013>$ F-tabel4,10) bukti yang menunjukkan bahwa F-hitung > F-tabel luas lahan berpengaruh terhadap pendapatan petani karet sebesar 98,0\%, untuk luas lahan 1-2 Ha F-hitung > F-tabel (Fhitung141.963 > F-tabel 4,75) variabel luas lahan terhadap pendapatan sebesar 93,4\%, untuk luas lahan $>\mathrm{Ha}$ Fhitung $>$ Ftabel (Fhitung 442.300> F-tabel 5,99) pengaruh variabel luas lahan terhadap pendapatan sebesar $98,4 \%$.

Sedangkan penelitian yang di lakukan Hermantoro (2009), dengan judul "Modeling and Simulation of Palm Oil Plantation Productivity Based on Land Quality and Climate Using Artificial Neural Network". Berdasarkan data yang berhasil dikumpulkan dapat dianalisis hubungan antara parameter secara tunggal dengan produktivitas lahan perkebunan kelapa sawit sebagai berikut : defisit air dan temperatur rata-rata berkorelasi negatif terhadap produktivitas perkebunan kelapa sawit. Hal tersebut sesuai dengan pernyataan Caliman (1998) bahwa bulan kering dapat menurunkan produksi kelapa sawit, sebagai contoh di Lampung dan Palembang akibat dari defisit air 100 $\mathrm{mm}$ akan mengurangi hasil $8-10 \%$ pada tahun pertama dan $3-4 \%$ pada tahun kedua.

Berdasarkan hasil dan metode penelitian yang di lakukan oleh peneliti sebelumnya, peneliti ingin mengkombinasikan proses dengan mensimulasikan data untuk mendapatkan hasil makasimal antara kelapa sawit dan karet, sehingga masyarakat tidak ragu untuk menanam atau berkebun berdasarkan hasil simulasi. Hasil mempengaruhi terhadap perekonomian masyarakat demi meningkatkan kesejahteraan keluarga mereka. Masyarkat berkenginan untuk bertani dengan waktu yang singkat dan modal yang sedikit agar cita dan kesejahteraan tercapai.

\section{METODE}

Untuk mempermudah dalam pengerjaan penelitian ini, maka penulis membuatkan kerangka kerja penelitian yang terdiri dari beberapa tahap, seperti pada gambar berikut ini.

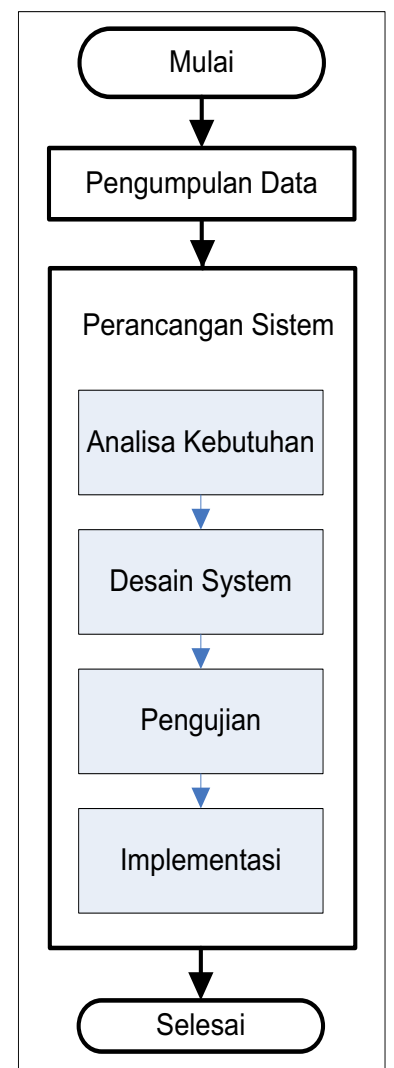

Gambar 1. Kerangka Kerja Penelitian

\section{Pengumpulan Data}

Teknik pengumpulan data yang dilakukan pada penelitian ini adalah : 


\section{Studi Pustaka}

Studi pustaka adalah metode pengumpulan data dengan cara membaca jurnal-jurnal yang teraik dan terkini (20092017) dan sumber lainnya yang berhubungan dengan masalah yang diteliti.

\section{Studi Lapangan}

Studi lapangan adalah metode pengumpulan data yang dilakukan dengan cara pengamati langsung objek yang diteliti untuk mendapatkan data-data. Pengamatan dilakukan dengan cara wawancara (Interview) dengan bertatap muka langsung dengan melakukan tanya jawab dengan Dokter Hewan, sehingga diperoleh beberapa pernyataan yang akan analisa sebelum pengambilan keputusan.

\section{Perancangan Sistem}

Perancangan sistem analisa metode certainty factor untuk mendeteksi penyakit kulit kucing berdasarkan beberapa tahap, yaitu :

\section{Analisa Kebutuhan}

Setelah seluruh data diperoleh, proses selanjutnya yang dilakukan adalah analisa data yang diperoleh dari hasil wawancara dan menyusun secara sistematis. Data di organisasikan ke dalam kategori, menjabarkan ke dalam unit-unit, menyusun ke dalam pola, sehingga memudahkan untuk sistem yang di desain pada tahap berikutnya.

\section{Desain System}

Tahap desain yang dilakukan adalah :

a. Pembuatan flowchart Sistem untuk memperjelas prosedur sistem, context diagram dan data flow diagram (DFD) untuk sistem, dan entity relationship diagram (ERD) untuk memperjelas hubungan antara suatu entitas dengan entitas lain.

b. Setelah melakukan pembuatan flowchart.

c. Membuat desain database menggunakan DFD sistem, dan ERD, maka dibuatlah perancangan antar muka (interface) untuk sistem.

\section{Pengujian}

Proses pengujian berfokus pada logika internal perangkat lunak, memastikan bahwa semua dinyatakan sudah di uji, dan pada eksternal fungsionalitas, yaitu mengarahkan pengujian untuk menemukan kesalahan - kesalahan dan memastikan bahwa input yang dibatasi akan memberikan hasil faktual yang sesuai dengan hasil yang dibutuhkan.

\section{Implementasi}

Implementasi aplikasi dilakukan dengan mengacu kepada perancangan aplikasi. Implementasi perangkat lunak dilakukan dengan menggunakan bahasa pemrograman PHP dengan software dreamweaver. Pada pembuatan database sistem analisa metode certainty factor, digunakan Database Manajemen System (DBMS) MySQL dengan software XAMPP.

\section{HASIL \\ Analisis sistem}

Dari hasil penelitian yang dilakukan, maka dapat ditemukan data-data untuk membuat Sistem Produksi Kelapa Sawit Dan Karet Dengan Membandingkan Hasil Produksi Menggunakan Simulasi Di Kuantan Singingi. Dari hasil pengolahan data dapat diperoleh, yaitu :

1. Luas lahan

2. Jenis Bibit/Kelapa sawit dan Karet

a. Dura

b. Psifera 
c. Tenera

3. Bahan olah karet

a. Karet Alam Kompensional

b. Lateks pekat

c. Karet Bongkah atau block rubber

d. Karet spesifikasi teknis atau crumb rubber

e. Tyre rubber

f. Karet reklim atau reclaimed rubber

4. Pembersihan

5. Pemupukan

\section{Analisis kebutuhan}

Kebutuhan user

Kebutuhan user meliputi apa saja yang dibutuhkan user pada Sistem Produksi Kelapa Sawit Dan Karet, yaitu :

1. Melakukan simulasi perbandingan antara produksi karet dan sawit.

2. Melakukan mengisian form buku tamu.

3. Artikel tentang kelapa sawit dan karet

\section{Kebtuhan admin}

Kebutuhan admin pada Sistem Produksi Kelapa Sawit Dan Karet adalah apa yang dibutuhkan oleh admin yaitu:

Melakukan proses login terhadap sistem.

1. Mengolah data admin.

2. Mengolah buku tamu.

3. Mengolah data bahan

4. Mengolah data harga.

5. Mengolah data simulasi

\section{Analisa sistem simulasi}

\section{flowcart sistem yang sedang berjalan}

Aliran sistem yang sedang berjalan adalah gambaran atau diagram alir yang menggambarkan suatu sistem yang sedang berjalan proses pemilihan dan penanaman kelapa sawit dan karet, yaitu:

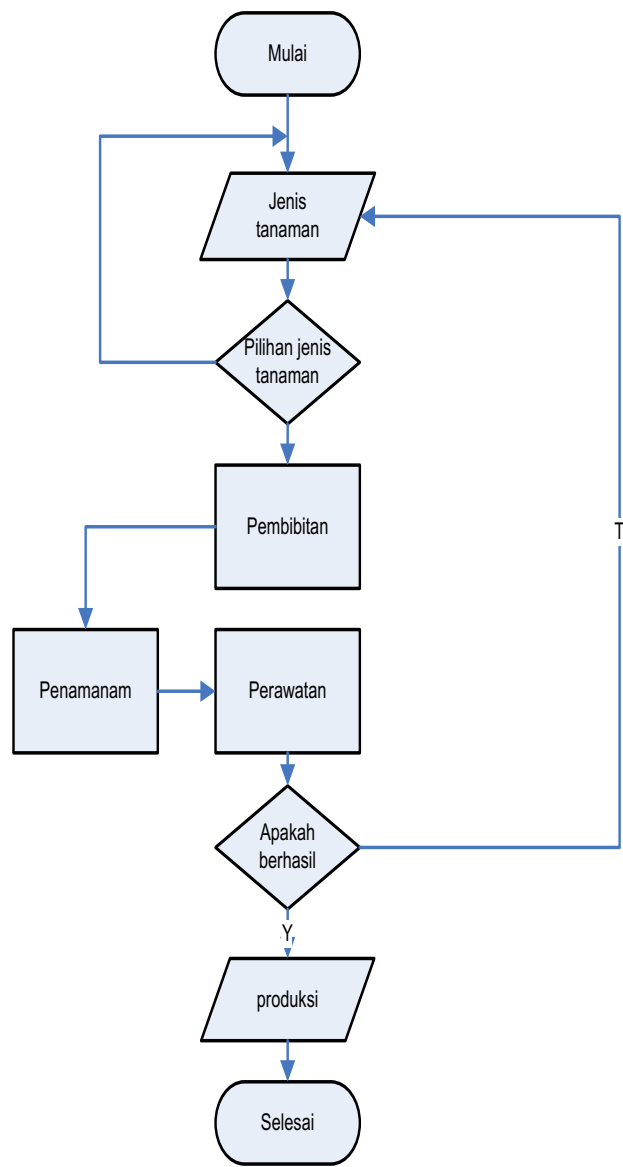

Gambar 2. Flowchar Sistem Yang Sedang Berjalan

Berdasarkan pada Gambar 2 dapat dijalaskan bahwa proses penanaman hingga menentukan hasil produksi yang akan di capai. Dimana user bisa memasukkan jenis tanaman, kemudian pilih jenis tanaman yang akan di jadikan simulasi, setelah itu melakukan proses pembibitan, penanaman, perawatan. Setelah melakukan semua proses tersebut maka akan di dapat hasil dengan kategori berhasil atau tidak, jika berhasil maka mendapatkan produksi yang maksimal, dan jika tidak berhasil maka harus mengulang proses lagi.

\section{Pengembangan aplikasi \\ Context diagram}

Konteks diagram (Context Diagram) digunakan untuk menggambarkan hubungan input dan output antara sistem dengan 
entitas luar, suatu diagram konteks selalu memiliki satu proses yang mewakili seluruh sistem. Sistem ini memiliki dua buah eksternal entity yaitu Admindan User.

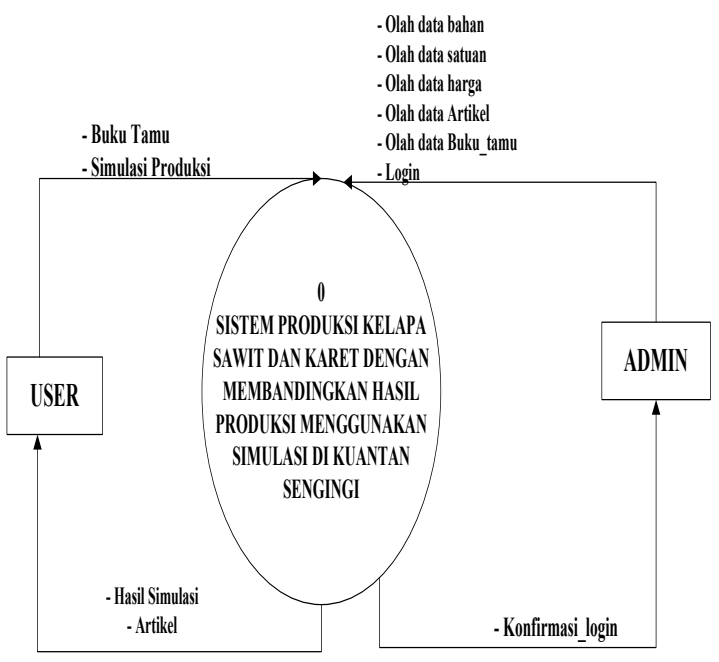

Gambar 3. Kontek Diagram

Pada gambar 3 diatas dijelaskan bahwa Admin memiliki peran mengelola seluruh data yaitu data bahan, data satuan, data harga, data artikel, data buku tamu, dan login. User memiliki peran input data buku tamu, dan simulasi produksi. Kemudian User juga mendapatkan output hasil simulasi dan artikel.

\section{Data flow diagram (DFD)}

Data flow diagram (DFD) akan menjelaskan alur sistem, DFD ini juga akan menggambarkan secara visual bagaimana data tersebut mengalir, pada perancangan simulasi produksi Kelapa Sawit dan Karet, yaitu :

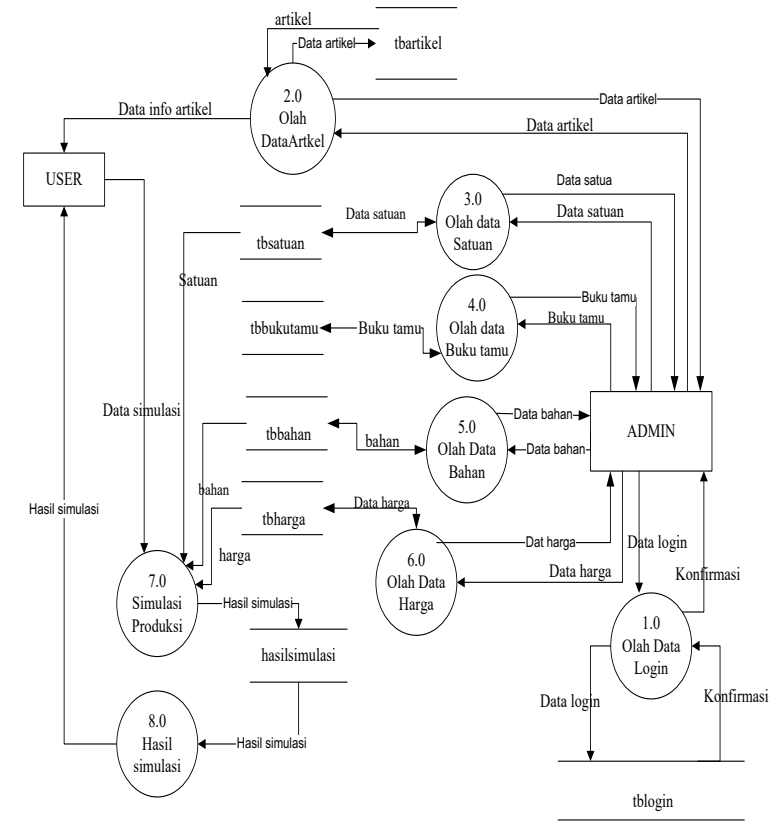

Gambar 4. Data Flow Diagram Level 1

Pada gambar 4 DFD level 1 memiliki 2 Entitas yaitu User dan Admin, memiliki 7 proses yaitu artikel, satuan, buku tamu, bahan, harga, login, dan simulasi produksi, sedangkan data store terdapat 6 tabel. Dimana entitas user hanya bisa melihat atau memasukkan data tampa bisa mengelola data atau merubah data pada database. Admin memiliki 5 aliran data, yaitu buku tamu, data login, data satuan, data artikel, dan data bahan. Sedangkan untuk user terdapat aliran data inforamsi dan data simulasi.

\section{Entity relationship diagram (ERD)}

Entity relationship diagram adalah suatu presentasi model data yang ada pada sistem terdapat entitas (entity) dan relasi (relationship) dapat berupa nyata berupa objek. 


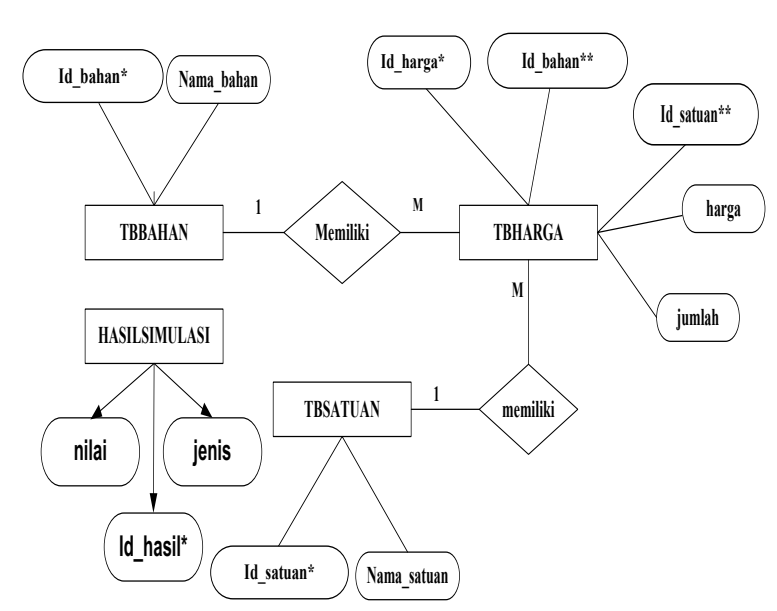

Gambar 5. Entity Relationship

Diagram (ERD)

Pada gambar 5 merupakan ERD untuk menentukan relasi antar tabel yang ada dalam database, relasi tersebut terdiri dari 4 tabel, yaitu tabel bahan, tabel harga, tabel hasil simulasi, dan tabel satuan. Dalam membuat relasi terdapat atribut masingmasing tabel, yaitu :

1.Table bahan terdiri dari atribut idbahan dan nama_bahan.

2.Tabel harga terdiri dari atribut idharga, idbahan, id_satuan, harga, dan jumlah.

3.Tabel satuan terdiri dari atribut id_satuan dan nama_satuan.

4.Tabel hasil simulasi terdiri dari atribut id_hasil, nilai, dan jenis

Berdasarkan 4 relasi table tersebut dapat di simpulkan bahwa ke semua tabel saling terhubung dan berhubungan di tunjukkan dengan primery key dan forign key

\section{Rancangan tabel}

Rancangan tabel merupakan kelanjutan dari analisa data Entity Relationship Diagram (ERD). Entitas-entitas pada ERD akan menjadi tabel pada database untuk media penyimpanan dari data-data yang diinputkan sebagaimana yang dibutuhkan dalam memperoleh informasi atau laporan.

a. Login

Tabel login berfungsi menyimpan data login. Setiap penambahan, pengurangan, dan pengeditan data login akan mempengaruhi tabel login.

b. Bahan

Tabel bahan berfungsi menyimpan data bahan. Setiap penambahan, pengurangan, dan pengeditan data bahan akan mempengaruhi tabel bahan.

c. buku tamu

Tabel buku tamu berfungsi menyimpan data buku tamu. Setiap penambahan, pengurangan, dan pengeditan data buku tamu akan mempengaruhi tabel buku tamu.

d. harga

Tabel harga berfungsi menyimpan data harga. Setiap penambahan, pengurangan, dan pengeditan data harga akan mempengaruhi tabel harga.

e. artikel

Tabel artikel berfungsi menyimpan data artikel. Setiap penambahan, pengurangan, dan pengeditan data artikel akan mempengaruhi tabel artikel.

f. satuan

Tabel satuan berfungsi menyimpan data satuan. Setiap penambahan, pengurangan, dan pengeditan data satuanakan mempengaruhi tabel satuan.

g. hasil simulasi

Tabel Hasil simulasi berfungsi menyimpan data hasil olahan dari simulasi dari sistem. Setiap penambahan, pengurangan, dan pengeditan data simulasi mempengaruhi hasil yang ada dalam data tabel simulasi.

\section{Rancangan antar muka}

Rancangan antar muka adalah desain untuk antarmuka sistem sebelum dilakukan 
pembuatan sistem di desain program. Desain interface meliputi desain tampilan utama, desain tampilan login, struktur menu, desain input dan desain output.

\section{Tampilan antar muka user a. halaman utama}

Halaman Utama merupakan tampilan data utama yang terdiri dari menu, header, footer, dan halam tengah. Gambar Halaman utama dapat dilihat pada Gambar 6 :

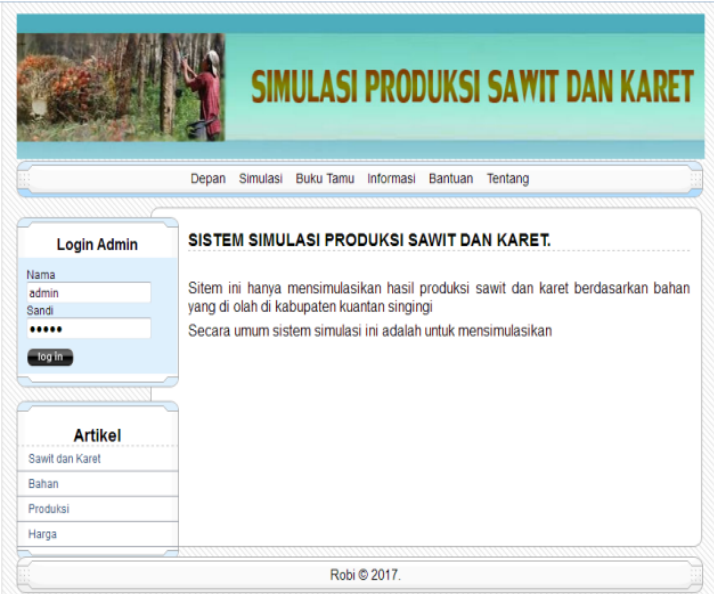

Gambar 6. Tampilan Halaman Utama

b. halamam pilihan simulasi

Halaman pilhan simulasi adalah tabel untuk mencetak data pilihan simulasi. Tabel data simulasi bisa dicetak dari sistem simulasi produksi Kelapa Sawit dan Karet. Gambar dapat dilihat pada Gambar 7

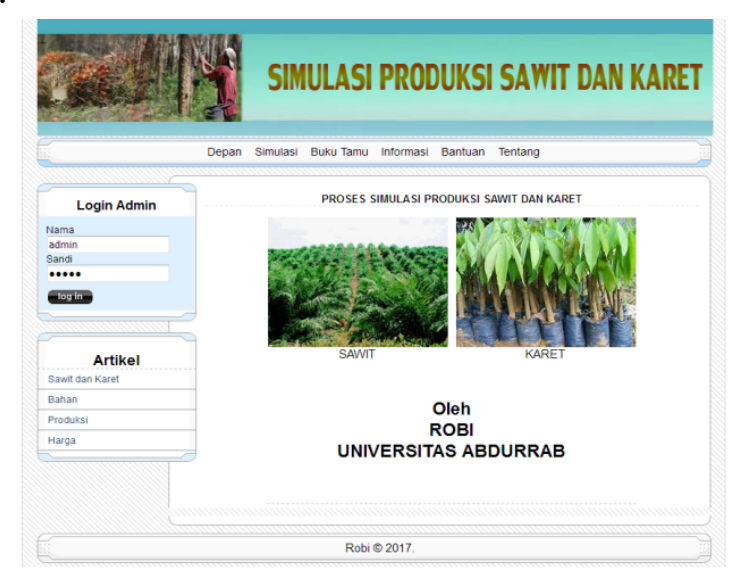

Gambar 7. Tampilan Pilihan

Simulasi
c.Halaman pengisian simulasi

Halaman Pengisian Simulasi Produk Kelapa Sawit dan Karet adalah tabel untuk mencetak data Pengisian Simulasi Produk Kelapa Sawit dan Karet. Gambar dapat dilihat pada Gambar 8 :

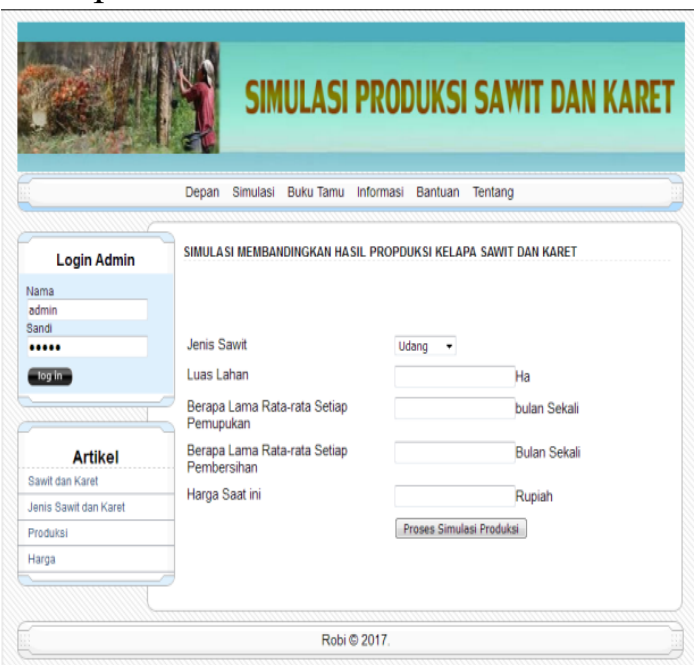

Gambar 8. Tampilan Pengisian Simulasi

\section{d.Halaman buku tamu}

Halaman buku tamu adalah tabel untuk mencetak data buku tamu. Gambar dapat dilihat pada Gambar 9 :

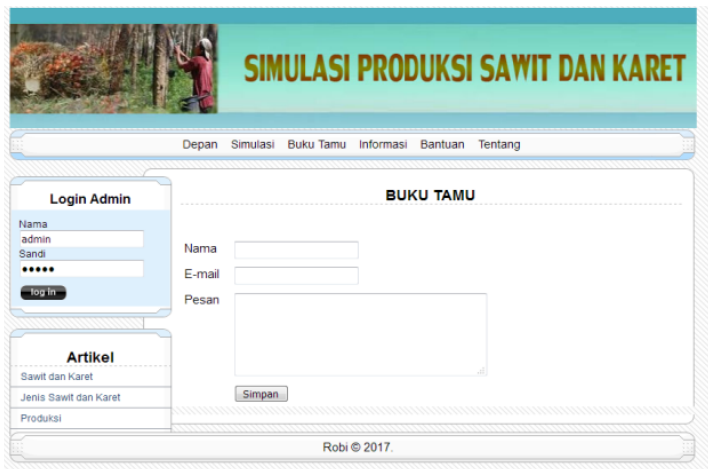

Gambar 9. Tampilan Buku Tamu

\section{e.Halaman informasi}

Halaman informasi adalah tabel untuk mencetak data informasi. Tabel inforamsi bisa dicetak dari inforamsi. Gambar dapat dilihat pada Gambar 10 : 


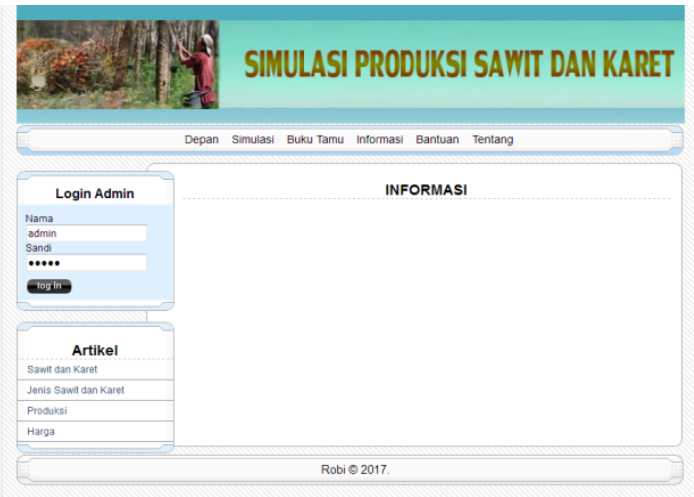

Gambar 10. Tampilan Informasi

f.Halaman bantuan

Halaman bantuan adalah tabel untuk mencetak data bantuan. Tabel bantuan bisa dicetak dari bantuan. Gambar dapat dilihat pada Gambar 11 :

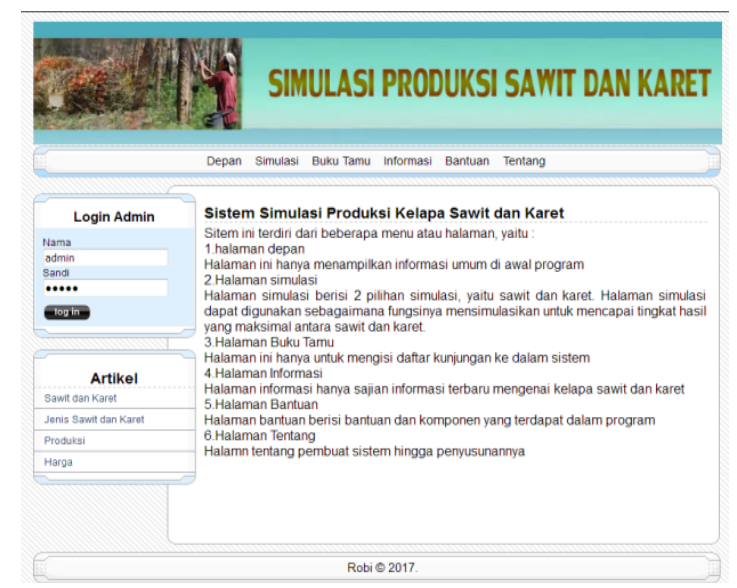

Gambar 11. Tampilan Bantuan

\section{g.Halaman tentang}

Halaman Tentang adalah tabel untuk menentukan data pembuat sistem. Gambar dapat dilihat pada Gambar 12 :

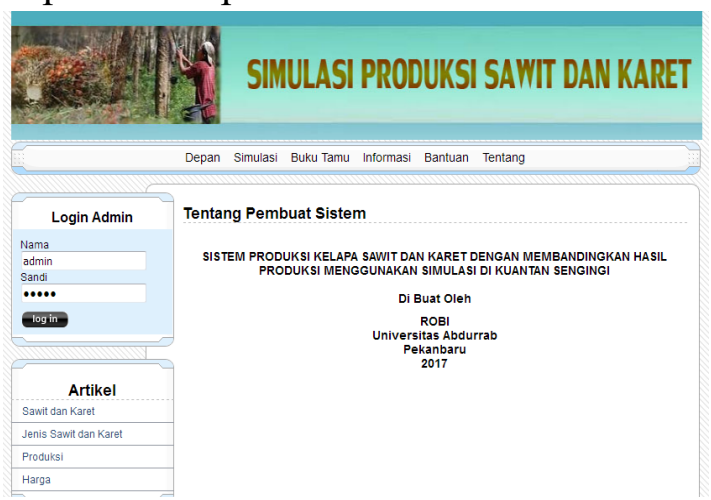

Gambar 12. Tampilan Tentang
2. Tampilan antar muka admin

a. halaman utama admin

Halaman utama admin adalah tabel untuk mencetak data utama admin. Tabel data utama admin bisa dicetak dari sistem simulasi produksi Kelapa Sawit dan Karet. Dapat dilihat pada Gambar 13 :

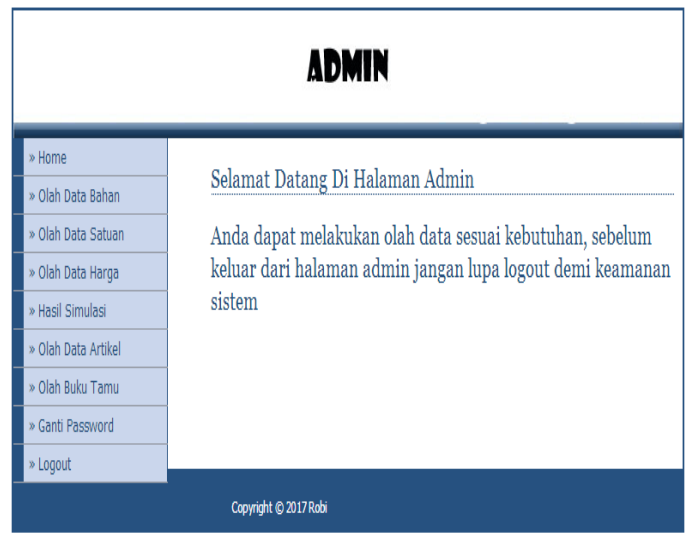

Gambar 13. halaman utama admin

\section{b. Halaman lihat data}

Halaman lihat data adalah tabel untuk mencetak data lihat data. Tabel data lihat data bisa dicetak dari sistem simulasi produksi Kelapa Sawit dan Karet. Dapat dilihat pada Gambar 14 :

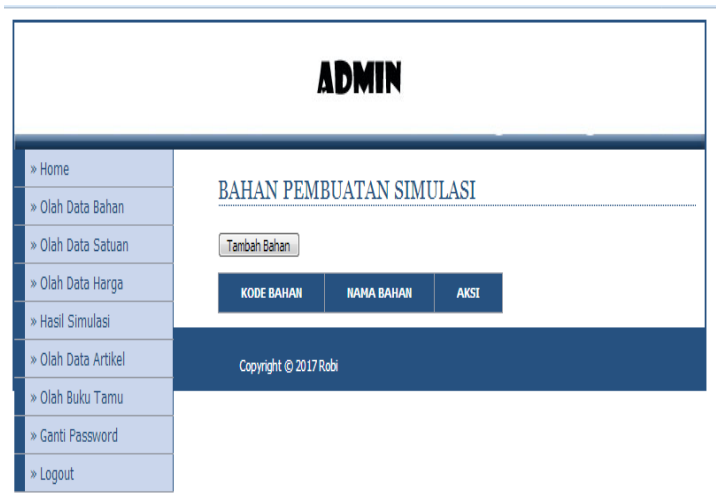

Gambar 14. Tampilan Lihat Data

c. Halaman tambah data

Halaman tambah data adalah tabel untuk mencetak data tambah data. Tabel data tambah databisa dicetak dari sistem 
simulasi produksi Kelapa Sawit dan Karet. Gambar dapat dilihat pada Gambar 15 :

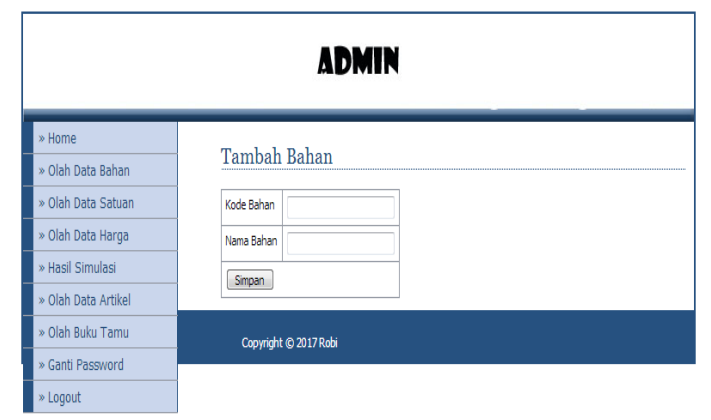

Gambar 15. Tampilan Tambah Data

\section{d. Halaman ubah data}

Halaman ubah data adalah tabel untuk mencetak data ubah data. Tabel data ubah data bisa dicetak dari sistem simulasi produksi Kelapa Sawit dan Karet. Gambar dapat dilihat pada Gambar 16 :

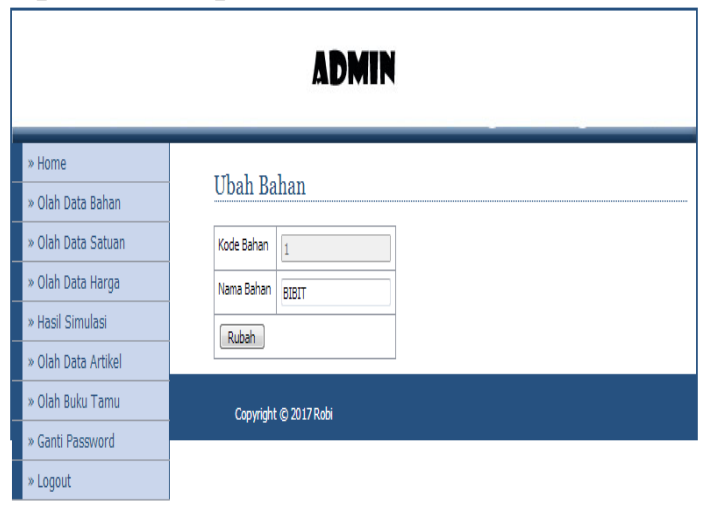

Gambar 16. Tampilan Ubah Data

\section{KESIMPULAN}

Adapun kesimpulan yang dapat di ambil dari sistem simulasi perbandingan hasil produksi antara kelapa sawit dan karet, yaitu:

1. Sistem simulasi produksi antara kelapa sawit dan karet sudah bisa disimulasikan dengan menggunakan aplikasi dengan menghasilkan perbedaan yang sangat jelas.

2. Sistem simulasi bisa memprediksi hasil perbedaan kedua tanaman berdasarkan jenis, dan proses perawatan sehingga menghasilkan atau berbuah dengan aplikasi yang dibangun menggunakan bahasa pemograman PHP.

Beberapa saran yang dapat penulis berikan adalah :

1. Dalam proses peralihan sistem dari menggunakan sistem yang lama kesistem yang dibangun hendaknya dilakukan secara bertahap oleh administrator, untuk menghindari terjadinya kesalahan dalam menjalankan aplikasi.

2. Untuk peneliti berikutnya diharapkan dapat mengembangkan sistem simulasi produksi lebih komplek perbandingan agar lebih akurat dan tepat prediksi keuntungan dan modal.

\section{DAFTAR PUSTAKA}

[1]Akhbianor, 2015, Strategi Petani Swadaya Kelapa Sawit Dalam Mengelola Perkebunan Kelapa Sawit Di Desa Sungai Kupang Jaya Kecamatan Kelumpang Selatan Kabupaten Kotabaru. PG (Jurnal Pendidikan Geografi) Volume 2, No 2, Maret 2015 Halaman 1-15. eISSN : 2356-5225

[2]Agustina, 2015. Pengaruh Luas Lahan Terhadap Pendapatan Petani Karet Di Desa Pulau Ingu Kpecamatan Benai Kabupaten Kuantan Singingi, JOM Vol $\underline{2,}$

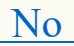
1. https://jom.unri.ac.id/index.php/JOMFKI $\mathrm{P} /$ article/view/5623

[3]Anonim, Panduan Lengkap Karet, Penebar Swadaya, Jakarta, 2012

[4]Arman. Yudha, 2008, Perencanaan dan Pengendalian Produksi, Graha Ilmu Yogyakarta.

[5]Chosmin S. Widodo dan Jasmadi. Panduan Menyusun Bahan Ajar Berbasis Kompetensi. Jakarta: Elex media Komputindo, 2008 
[6]Ekoanindiyo, Ardiansyah Firman. 2011. Pemodelan Sistem Antrian dengan Menggunakan Simulasi. Jurnal Dinamika Teknik, Volume: V, No. 1.

[7]Hardjowigeno, 2007, Ilmu Tanah, Pusaka Utama, Jakarta

[8] Hasan, M. Iqbal. 2002. Pokok-Pokok Materi:Teori Pengambilan Keputusan, Jakarta: Ghalia Indonesia.

[9] Hermantoro, Modeling and Simulation of Palm Oil Plantation Productivity Based on Land Quality and Climate Using Artificial Neural Network, J.Agromet 23 (1): 45-51,2009

[10] Jogiyanto,2005.Metodologi Penelitian Sistem Informasi. CV Andi Offset. Yogyakarta

[11] Kristanto.2008. Perancangan Sistem Informasi dan Aplikasinya Gava Media, Yogyakarta.

[12] Matnuh. (2012). Pengertian Keberanian. Tersedia dalam id.shvoong.com/humanities/theorycritism/2291563pengertian-

keberanian/. [Online]. Diunduh tanggal 06 Maret 2017 pukul 13.31 WIB.

[13] Nugroho,2008. Analisa dan Perancangan Sistem Informasi dengan metologi Berorientasi Objek, Penerbit Informatika, Bandung

[14] Peranginangin, Kasiman. 2006. Aplikasi WEB dengan PHP dan MySQL, Yogyakarta: Andi.

[15] Prihati, Yani. 2012. Simulasi dan Pemodelan Sistem Antrian Pelanggan di Loket Pembayaran Rekening XYZ Semarang. Jurnal Informatika, Volume: 3, No. 3.

[16] Sari, 2010. Evaluasi Sistem Produksi Dengan Membandingkan Hasil Produksi Menggunakan Metode Simulasi.Teclino Science Vo.4 No.2
[17] Sari. 2015. Analisis Faktor Yang Mempengaruhi Alih Fungsi Lahan Karet Menjadi Lahan Sawit Pada Anggota Kud Langgeng Kecamatan Logas Tanah Darat Kabupaten Kuantan Singingi. JOM 2 . https://jom.unri.ac.id/index.php/JOMF KIP/article/view/7214. 